Јелена М. Андрић

yeye9001@gmail.com

Данка 3. Спасојевић

dankamikaric@gmail.com

Народна библиотека

„Стефан Првовенчани” Краљево
Стручни рад

UDK 007:027.54]:004(497.11)

616.98:578.834(100)"2020"

https://doi.org/10.18485/bibliotekar.2020.62.2.7

\title{
ОРГАНИЗАЦИЈА И ИЗАЗОВИ У РАДУ НАРОДНЕ БИБЛИОТЕКЕ „СТЕФАН ПРВОВЕНЧАНИ” КРАЉЕВО У ДОБА ПАНДЕМИЈЕ
}

Сажетак: Овим радом представљен је начин на који је реорганизована делатност краљевачке библиотеке у измењеним условима пословања узрокованих пандемијом. Приказано је са којим изазовима су суочени библиотекари у контексту нове форме комуникације са корисницима, засноване углавном на примени дигиталних технологија. Указано је на специфичности корисничке перцепције измењеног режима позајмице књига. Предочени су модели коришћења дигиталних платформи у оквиру промотивне, програмске и радионичарске делатности Библиотеке, услед ограничења окупљања у затвореном простору. Намера је била да се лоцирају слабости у пословању, које су се испољиле у специфичним околностима, како би се стечена искуства применила у ревидирању циљева и планирању развоја.

Кључне речи: библиотека, руковођење, пандемија, дигиталне платформе, онлајн радионице, друштвени медији.

\section{Увод}

Сагледавајући позицију савремене библиотеке на прагу 21. века, Жељко Вучковић полази од поставке о библиотекама као живим оріанизмима у којима библиоиечечка йонуgа сиивара йойражну, односно утиче на

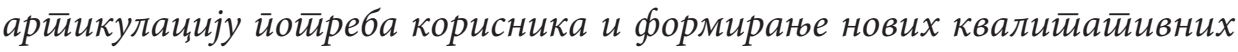


йотиреба. ${ }^{1}$ Чини се да истакнуто полазиште о библиотекама као културним субјектима у сталном процесу промене и прилагођавања, никада није добило чвршће упориште но у доба и даље актуелне пандемије, као социјално свеобухватне, кризне ситуације, којом су коренито уздрмане и са великим изазовом суочене све сфере друштвеног живота. Осим што је донела глобалну неизвесност, пандемија је наметнула потребу за трансформацијом и прилагођавањем, па се у околностима свеколиких ограничења, степен адаптабилности и флексибилности показао као кључни чинилац за очување континуитета и успешности у пословању. У контексту пандемије, за библиотеке је било неопходно следити дефиницију савременог руковођења као адекватног реаіована на кризне сийуације, кулииивисане односа са сииољним светиом, ирикуйљьане и дисеминирағе информачија, као и сйособности ga се уіраби зіолна йрилика. ${ }^{2}$ Од руководилаца се очекивало одлучно управљање и брзо доношење одлука, док су библиотекари били пред изазовом изналажења креативних и алтернативних решења за очување контакта са корисницима и присуства у јавном простору у нагло и драстично измењеним околностима функционисања библиотечке делатности. У настојању да терминолошки сведемо овакве захтеве, долазимо до формулације gинамички йрисии $\bar{u}^{3}$ у управљању библиотеком, који подразумева сииално ӣрилаїођаваюе ӣоиребама корисника у йроменльвим условима ${ }^{4}$ јер само разумевање њихових захтева није довољно. Осим тога, у условима пандемије, до пуног изражаја дошли су потенцијали дигиталних ресурса, као и оправданост давно измењене семантике појма библиотеке

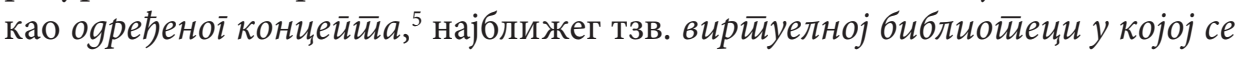
информације обезбеђују кроз комуникационе мреже вище неіо gирекйним контиактиом са физичким колекиијама докуменатиа. ${ }^{6}$

Поред појединости у вези са организацијом пословања у Народној библиотеци „Стефан Првовенчани” Краљево, које се односе на правну регулативу и делегирање запослених за одређене задатке, у наставку ће бити речи о уоченим специфичним захтевима корисника у процесу позајмице

Жељко Вучковић, Ка савременој библиоиееии (Нови Сад: Библиотека Матице српске, 1997), 23.

Вучковић, Ка савременој библиотещи, 87.

Весна Д. Жупан, Маркейині̄ у библиотеккама (Београд: Свет књиге, 2001), 23.

Жупан, Маркетинг у библиотекама, 23.

Вучковић, Ка савременој библиотеци, 107.

Вучковић, Ка савременој библиотеци, 108. 
књига у ограничавајућим условима, као и о коришћењу дигиталних ресур-

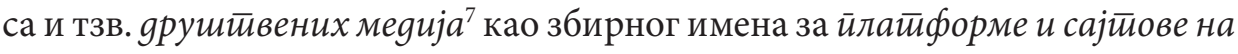

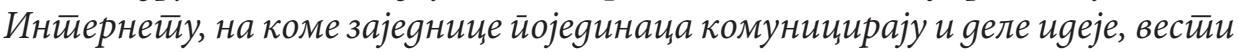
u оgређене инйересе, ${ }^{8}$ а којима је у измењеним друштвеним околностима припала превласт у процесу реорганизовања рада библиотеке у односу на традиционалне моделе у домену програмске, радионичарске и промотивне активности библиотеке.

\section{Организација рада краљевачке библиотеке у условима пандемије}

Проглашење пандемије и касније увођење ванредног стања у нашој земљи, били су праћени одлукама и смерницама републичког кризног штаба и локалних кризних штабова у вези са спровођењем превентивних мера за спречавање ширења болести ковид-19, као и препорукама за реорганизовање рада установа у условима пандемије. Следствено тим упутствима, рад са корисницима у краљевачкој библиотеци обустављен је одмах по увођењу ванредног стања, 16. марта 2020. године, па је уследила и нужна прерасподела и измена радних ангажмана запослених, с обзиром на то да је део запослених упућен на рад од куће, првенствено из здравствених или породичних разлога, када је реч о родитељима деце млађе од 12 година. Примарна обавеза послодавца у процесу прилагођавања пандемијским условима била је усвајање правне регулативе у вези са заштитом здравља запослених и корисника, и спречавањем ширења заразе, као и њено доследно спровођење у пракси. У том смислу, било је посебно важно доношење трију докумената, и то: Акйа о йроцени ризика (којим се уређује посебан начин и организација рада у Народној библиотеци Сйебан Првовенчани Краљево), Правилника о оріанизаиији раgа тиоком тирајаға ванреgної сииана збої заразне болестии COVID-19 и йостиуйану зайослених и раяно анїажованих лица у библиотеци (којим се уређује организација рада Народне библиотеке Сйефан Првовенчани Краљево током трајања ванредног стања и поступања запослених, радно ангажованих лица и корисника услуга у циљу свођења на најмању могућу меру могућности обољевања и

Cecilia Figureoa, Uvod u digitalni marketing (Beograd: Kompjuter biblioteka, 2020), 42.

8 Cecilia Figureoa, Uvod u digitalni marketing, 42. 
преношења заразне болести COVID-19 код запослених, радно ангажованих лица и корисника услуга Библиотеке) и Плана ирримене ирревенииивних мера за безбедан и зярав раg за сиречаване йојаве и ширень ейияемије заразне болести $\mathrm{COVID-19}$ изазване вирусом SARS-CoV-2 (којим се за сва радна места у радној околини, утврђују превентивне мере од утицаја на безбедност и здравље на раду запослених и корисника). Иако је реч о формалноправној регулативи, у којој нема простора за импровизацију и варирања, у условима ванредног стања, које је било праћено обиљем информација, од веродостојних до крајње непоузданих, за брз проток релевантних и кредибилних информација и размену искустава, као једног од темељних постулата савременог руковођења, и то у околностима у којима је једина извесност била управо неизвесност, још једном је у пракси потврђен значај умрежености установа културе, било интерне, или посредством удружења какво је Библиотекарско друштво Србије, које је умногоме преузело улогу дисеминационог информативног сервиса и поставило се као чврст ослонац струци.

Када је реч о прерасподели и измени радних ангажмана запослених, настојали смо да изнађемо оптимална решења која би се темељила на бризи за очување здравља запослених, једнако као и на потреби задржавања одређеног нивоа продуктивности, без обзира на чињеницу да је рад са корисницима обустављен. Од укупно 22 запослена библиотекара, 13 је упућено на рад од куће, из здравствених или породичних разлога које смо претходно истакли, са радним задацима у сфери дигитализације завичајне грађе (аналитика), завичајног пресклипинга, каталогизације, уредничких послова и припреме публикација у оквиру издавачке делатности Библиотеке, планирању набавке библиотечко-информационе грађе за 2020. годину, тестирању нове МБС базе и каснијем праћењу и уређивању МБС анкета за наше подручје матичности, као и у домену популарисања књиге и читања на друштвеним платформама које су се наметнуле као сврсисходан и, у овим околностима, једини ресурс за чување везе са корисницима. Остали библиотекари, који су током ванредног стања били радно ангажовани у Библиотеци, бавили су се уређивањем и реорганизацијом фондова, као послу који се никада не завршава.

И након укидања ванредног стања, те отварања Библиотеке за кориснике, један део библиотекара остао је у режиму рада од куће, сада искључиво из здравствених разлога, с обзиром на то да је обновљен и рад вртића, па нега деце више није била критеријум за упућивање на рад од куће. Библиотека је за кориснике отворена 11. маја 2020, после готово двомесечне паузе у сусретима са корисницима. Пред руководством и библиотекарима 
искрсао је наредни изазов успостављања новог концепта рада позајмних одељења и комуникације са корисницима у самој библиотеци у околностима пандемије.

\section{Долазак у библиотеку - позајмица књига и(ли) мали ритуали љубитеља књиге?}

Краљевачка библиотека поново је отворена за посете корисника 11. маја 2020. године, убрзо након укидања ванредног стања. Иако је јавна библиотека 21. века све више усмерена на различиие йийове корисника и

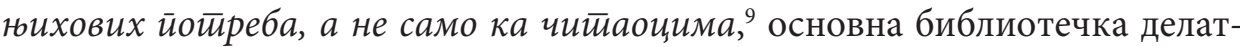
ност се, у широкој јавности, и даље најчешће поистовећује са позајмицом књига. Ослушкивањем корисничких утисака о организацији рада и функционисању Библиотеке током ванредног стања, као и њихове реакције по отварању и обнављању могућности доласка у физички простор или зграду Библиотеке, може се закључити да смо, у нашој локалној средини, још дубоко у ери читалаца, са тек плитким закорачењем у раздобље у којем се категорија читалаца усложњава и трансформише у категорију корисника библиотечких услуга. Готово без изузетка, доживљај читалаца/корисника је да је Библиотека била затворена током трајања ванредног стања, а обнављање рада Библиотеке изједначено је са тренутком у којем је поновно омогућена позајмица књига, уз потпуни превид чињенице да смо све време били присутни онлајн са немалом понудом разноликих дигиталних садржаја за одрасле и децу.

У складу са препорукама за примену превентивних мера за спречавање ширења заразе, функционисање одељења је модификовано и редуковано на више равни. Као и у свим затвореним просторима, уведена је обавеза ношења маски и држања физичке дистанце, ограничено је кретање кроз простор, забрањен је слободан приступ фондовима, а библиотекари су фаворизовали претходно наручивање књига електронским путем или телефоном, како би се скратио период боравка корисника у Библиотеци. У контексту примене наведених мера, библиотекари су наишли на отпор, недовољно разумевање и немирење корисника, па и разочарање најмлађих читалаца, због забране слободног бирања публикација. Њихова борба за

9 Јасмина Нинков, Библиотеке XXI века, (Београд: Чигоја штампа, 2010), 14. 
мало йарче раја у Библиотеци постала је свакодневица. Све је изразитија бивала површност општег утиска да људи у библиотеку долазе да задовоље жељу за знањем или да набаве књиге које ће им испунити часове доколице, а све утемељенији увид о доласку у библиотеку као својеврсном ритуалу у којем се сустичу разнолике потребе. Недвосмислена је оправданост закључка да је шетња кроз библиотечке фондове, бирање књига прелиставањем њихових страница и разгледањем корица, читањем резимеа и рецензија, заправо незамењива претходница читању, која, са ишчитавањем одабране књиге и сабирањем утисака о прочитаном, заправо чини целину читалачког процеса и даје пуноћу читалачком доживљају због чије се заводљивости поново долази у библиотеку. Ово би могло бити охрабрење

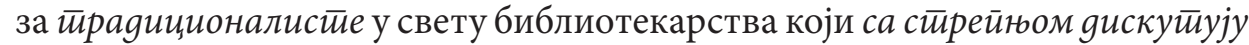
о моїућносии изумирағьа кюиіе у неном физичком облику. ${ }^{10}$

\section{Друштвени медији у библиотеци у доба пандемије user friendly ${ }^{11}$ концепт на делу}

Са становишта ауторки овог рада, као библиотекарки јавне библиотеке у релативно малој локалној средини, заснованог на праћењу свакодневне библиотечке праксе на позајмним одељењима, широко је заступљено конзервативно корисничко поимање библиотеке као места за чување и позајмицу књига, као и њено упрошћавање и поистовећивање са књижним фондовима. Ово опажање добило је снажну потврду у измењеном режиму рада у условима пандемије. Већ смо истакли увид да су чланови наше библиотеке више читияоии, а мање корисници библиотечких услуга, иако је идеја о user friendly концепту, који подразумева посвећеност кориснику, одавно истакнута као темељни постулат развоја савремене библиотеке. Измењене друштвене околности у доба пандемије, које су наметнуле и захтеве за реорганизовањем рада библиотеке, условиле су и појачано усредсређивање библиотекара на коришћење дигиталних

10 Љиљана Косијер, Криза чийаюа међу основношколичма и модели ублажаваюа юених йослеguи а (Нови Сад: Градска библиотека Нови Сад, 2017), 25.

11 У својој књизи Библиотеке XXI века, Јасмина Нинков говори о промени основног постулата пословања у јавним библиотекама, ca reader friendly (посвећеност читаоцу) до user friendly (посвећеност кориснику), што значи преструктурирање организације целокупне мреже библиотечких услуга. 
ресурса за очување контакта са корисницима и континуитета у раду. То је била и прилика за свакодневне непосредне увиде у ефикасност дигиталних ресурса у трансформацији једног, у значајној мери, традиционалног библиотечког система у жив и динамичан информациони центар. ${ }^{12}$ Премда се нови медији неретко посматрају у конфронйтиији са књиі̄oм, ${ }^{13}$ а традиционалисти их оптужују за gекаgенцију љуgскої gyxa, ${ }^{14}$ чини се да су, у доба пандемије и опште изолације, свеприсутне гласове о отуђењу и декаденцији узроковане дигиталним окружењем, надјачали гласови о њима као моћним средствима повезивања и држања на окупу изолованих и удаљених субјеката. У раздобљу у којем су онемогућени наши непосредни сусрети са корисницима, неговање куличуре gрушйвених мрежа, која

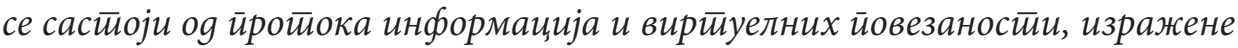
у ироцесима који иреовлаяавају у нашим кулитурним и симболичним животиима, ирроцесима размене и инйеракиије између физички нейовезаних йоложаја, ${ }^{15}$ испоставило се као императив.

Иако смо се и раније ажурно бавили маркетингом библиотеке у дигиталном простору, путем званичног сајта и друштвених мрежа, у условима пандемије интензивирали смо коришћење нових медија за представљање нашег рада, дељење информација, али и за нов облик програмске и радионичарске делатности. Прибегли смо широкој употреби интернета као ияеалноі начина gа се уйали свейло и йоgсейи на бројне библиойечке колекиије, фондове ститре и ретике книіе, завичајне фондове, као и на разноврсне

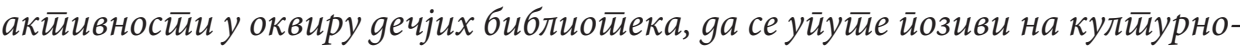
анимационе йроіраме, книжевне вечери, кониериие. ${ }^{16}$

До увођења ванредног стања, наше оглашавање на званичном сајту Библиотеке, као и објаве на друштвеним мрежама Фејсбук и Инстаграм, првенствено су имали промотивни и информативни карактер. У новим условима пословања у контексту пандемије, укидањем непосредних сусрета са корисницима, осим што је онемогућена позајмица књига, осујећена је и реализација богате програмске активности по којој је краљевачка

12 Вучковић, Ка савременој библиотеици, 106.

13 Косијер, Криза читиаға међу основношколиима и модели ублажаваюа юених йослеgии, 134.

14 Косијер, Криза чийаюа међу основношколиима и модели ублажаваюа юених йослеgииа, 25.

15 Хосе-Антонио Кордон-Гарсија, Хулио Алонсо-Аревало, Ракел Гомез Дијаз, Данијел Линдер,

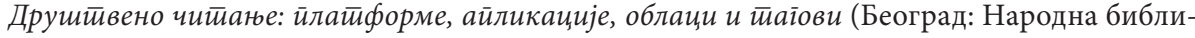
отека Србије, 2017), 14.

16 Нинков, Библиотеке ХХІ века, 16. 
библиотека препознатљива, као и одржавање радионица за децу. Затварањем физичког простора Библиотеке, наведене активности измештене су у виртуелно окружење. Тако смо готово свакодневно водили онлајн читалачки дневник, за одрасле и децу, чија је концепција подразумевала кратак књижевнокритички осврт на опус или одређено дело одабраног аутора, као и најупечатљивије цитате. На страницама нашег онлајн дневника читања за одрасле, нашли су се Борислав Пекић, Џ. М. Куци (John Maxwell Coetzee), Гордана Ћирјанић, Светислав Басара, Горан Петровић, Лав Николајевич Толстој (Лев Николаевич Толстой), Драган Великић, Кристијан Новак... Када је реч о дечјем читалачком дневнику, прилагођавајући га циљној групи, трудили смо се да буде сликовит и пријемчив, осмишљавајући странице налик малим изложбеним паноима колажног типа, са биобиблиографским подацима о аутору и илустрацијама које дочаравају представљене књиге. Намера је била подстаћи интерактивност и мотивисати децу да својим коментарима, утисцима и предлозима иницирају и учествују у креирању нових страница дневника. Говорили смо о Нилу Гејману (Neil Gaiman), Џону Грину (John Green), Стивену Хокингу (Stephen Hawking), Џенди Нелсон (Jandy Nelson), Роалду Далу (Roald Dahl), Михаелу Ендеу (Michael Ende), Хансу Кристијану Андерсену (Hans Christian Andersen), Антоану де Сент-Егзиперију (Antoine de Saint-Exupéry), Љyбивоју Ршумовићу, Мошу Одаловићу, Урошу Петровићу, Весни Алексић, Владислави Војновић, Јасминки Петровић, Гордани Тимотијевић, Дејану Алексићу, Добрици Ерићу, Игору Коларову, Гроздани Олујић, Десанки Максимовић... Свака објава била је допуњена или заокружена одабраним таговима са циљем увећања видљивости и претраживости самог имена наше Библиотеке и активности које у њој реализујемо, с обзиром на то да употреба тагова у дигиталном окружењу чини објаву јавном и активном и представља својеврсни метаподатак о теми и садржају објаве. ${ }^{17}$ Серијал постова страница читалачког дневника довео нас је до мале импровизоване онлајн књижевне радионице која се темељила на видео-записима дечјих препорука књига упућених њиховим другарима као изазовима за читање. Приказивањем преко четрдесет снимака које смо добили од наших пратилаца, 23. априла смо обележили Светски дан књиге и ауторских права. Дигитални књижевни сусрети постали су узбудљивији када смо увели и

17 О друштвеном читању, у контексту употребе платформи, апликација, облака и тагова,

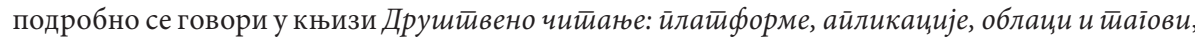
чији су аутори Хосе-Антонио Кордон-Гарсија, Хулио Алонсо-Аревало, Ракел Гомез Дијаз и Данијел Линдер. 
награђивање најмаштовитијих и најангажованијих пратилаца, а поклон су, очекивано, биле књиге и бесплатно чланство у Библиотеци. Ланац читања и виртуелног дружења са најмлађим корисницима, исплетен у месецима комуникације на даљину, остао је непрекинут и након враћања у Библиотеку, потврђујући велики потенцијал за промоцију књиге и читања, као и за даље повезивање и ширење мреже пратилаца, односно корисника или потенцијалних корисника Библиотеке. Охрабрени успехом књижевних дружења путем друштвених мрежа, покренули смо онлајн говорну радионицу, замишљену као сет говорних вежби које обједињују едукацију и забаву, позивајући децу да са интернет заједницом поделе снимке, архаичним језиком речено, језиколомки, тј. брзалица, које као изазов постављају познати дечји писци. Прву брзалицу задао је дечји писац Дејан Алексић. Успешност овог модела комуникације са децом, првенствено у сврху популарисања књиге и читања, поткрепљује оцену да деца йозийивно реаїуjy на іотово сваки вия анимације који за циль има буђене или иродубтиване ни-

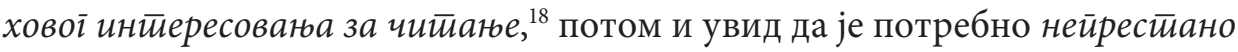

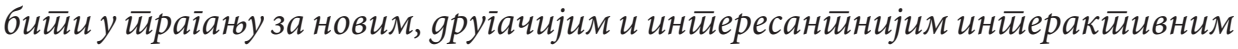
моделима ирристиуй йоиенцијалним читиаоцима, који захиевевју юихово акииивно учешће, ${ }^{19}$ те да се изузетно ефектним показује комбиновање традиционалних и дигиталних медија, какво је управо повезивање књиге или традиционалних језичких форми, попут брзалица, са производима дигиталних технологија.

Успешност онлајн сусретања са децом у покушају да надоместимо укинуте доласке у Библиотеку и учешће у радионицама, није довођена у питање, с обзиром на чињеницу да су управо деца и млади најмасовнији корисници друштвених мрежа и дигиталних технологија уопште, али је извесна бојазан постојала када је о одраслој популацији реч. Приволети их да прате понуђене програмске садржаје у дигиталној форми чинило се не нарочито тешким, али учинити виртуелну комуникацију са њима интерактивном деловало је неизвесно. Међутим, наша бојазан од неуспеха у очекивању одзива одраслих развејана је након пласирања онлајн квиза познавања књижевности и позива на учешће, као једној у низу дигиталних акција којима смо обележили Светски дан књиге. За само неколико сати по објављивању квиза имали смо више од двадесет такмичара, од којих су најбољи награђени књигама и бесплатном годишњом чланарином.

18 Косијер, Криза читиаюа међу основношколиима и модели ублажавана юених йослеgииа, 105.

19 Косијер, Криза чийаюа међу основношколиима и модели ублажаваюа юених йостеgииа, 110. 
Велику пажњу у нашој онлајн понуди изазвали су видео-записи програма реализованих у протеклих годину дана, пласираних на наш Фејсбук профил. Тако је широка и удаљена публика, окупљена у виртуелном простору, била у прилици да погледа предавања др Милоша Ковачевића, др Ивице Живковића, Светоссавску и Краљевgанску бесеgу, низ програма из серијала Изазови родительстива, Роколуйци, Тумачене библијских йексйова, Крај йуйа... Позивали смо, такође, на праћење наше дигиталне завичајне збирке, која се свакодневно обогаћује новим садржајима, на читање дигитализоване Повеље, приредили песнички матине са ауторским читањем поезије у оквиру којег су се представили Гордана Тимотијевић, Живорад Недељковић, Дејан Алексић, Драган Хамовић, Милоје Радовић и Милош Милишић.

У осмишљавању и пласирању дигиталних садржаја неопходно је непрестано имати свест о снажном и широком утицају дигиталних медија и њиховој великој улози у брендирању, па је важно пажљиво конципирати своје представљање на мрежи. Потенцијал дигиталних платформи може бити један од кључних инструмента ирреображаја йоиенцијалних корисника

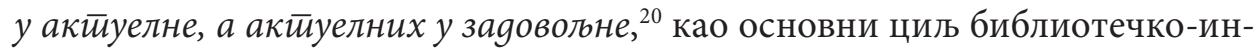
формационог система са аспекта развоја потреба корисника.

\section{Закључак}

Ако би требало резимирати делатност краљевачке библиотеке у специфичном раздобљу ванредног стања узрокованог пандемијом, као и даље актуелном околношћу, те сабрати искуства пословања у измењеним условима, а потом их учинити функционалним у процесу ревидирања циљева и планирања развоја, можемо закључити да нас је мноштво различитих ограничења учинило умногоме креативнијим и покренуло из зоне приличног степена инертности у вези са максималним упошљавањем дигиталних технологија у свим сегментима нашег деловања, почевши од промотивних активности, преко програмске делатности до радионичарског рада. Богата дигитална завичајна збирка, на пример, похрањена на мрежи, пуни смисао добија тек када се континуирано представља са циљем да постане предмет интересовања широког корисничког круга. Поред програма у физичком простору Библиотеке, требало би понудити и њихов онлајн пандан на мрежи, и учинити своје активности доступним и видљивим и

20 Вучковић, Ка савременој библиоиееии, 23. 
најудаљенијим корисницима. Исти принцип би требало следити и када је реч о радионицама. Упрошћавањем смисла профила на друштвеним мрежама њиховим свођењем на информативну улогу, занемарујући њихов потенцијал у подстицању интерактивности на релацији библиотека-пратиоци, пренебрегавамо њихову немерљиву улогу у процесу ширења своје корисничке мреже. Корисници, очито, одавно не би требало да буду само читаоци, нити су они везани за локалну средину. Утисак је, такође, да постоји очигледан отпор корисника према ултимативном увођењу дигиталне форме пословања, нарочито у сегменту позајмице књиге која је, посебно међу читаоцима, дефиниција традиционалне библиотеке. Кључ успеха је у непрестаном праћењу потреба корисника и њиховом саображавању модерним тенденцијама.

\section{Literatura:}

1. Figueroa, Cecilia. Uvod u digitalni marketing. Beograd: Kompjuter biblioteka, 2020.

2. Kordon-Garsija, Hose-Antonio et al. Društveno čitanje: platforme, oblaci i tagovi. Beograd: Narodna biblioteka Srbije, 2017.

3. Kosijer, Ljiljana. Kriza čitanja među osnovcima i modeli ublažavanja njenih posledica. Novi Sad: Gradska biblioteka, 2017.

4. Ninkov, Jasmina. Biblioteke XXI veka. Beograd: Čigoja štampa, 2010.

5. Vučković, Željko. Ka savremenoj biblioteci. Novi Sad: Biblioteka Matice srpske, 1997.

6. Župan, Vesna D. Marketing u bibliotekama. Beograd: Svet knjige, 2001. 
Jelena M. Andrić

yeye9001@gmail.com

Danka Z. Spasojević

dankamikaric@gmail.com

Public Library "Stefan Prvovenčani”, Kraljevo

\title{
ORGANIZATION AND CHALLENGES IN THE WORK OF THE PUBLIC LIBRARY “STEFAN PRVOVENČANI” IN KRALJEVO DURING THE PANDEMIC
}

\begin{abstract}
This paper presents how the activities of the Library were reorganized, in the changed conditions caused by the COVID-19 pandemic. Challenges that librarians have been faced with, in the context of communication based mainly on the application of digital technologies, are also presented. The specifics of the users' perception of the changed book lending regime are pointed out. The paper gives the models of using digital platforms in designing the promotional, program, and workshop activities of the Library, due to restrictions of gatherings on the premises. The intention is to locate weak points, manifested in specific circumstances, in order to apply the acquired experience in revising goals and planning future development.
\end{abstract}

Keywords: library, management, pandemic, digital platforms, online workshops, social media.

Примљено: 9. септембра 2020.

Исправке: 12. октобра 2020.

Прихваћено: 27. октобра 2020. 